\title{
Grice's Conversational Implicature: A Pragmatics Analysis of Selected Poems of Audre Lorde
}

\author{
Adaoma Igwedibia*
}

Department of English and Literary Studies, University of Nigeria, Nsukka., Enugu State, Nigeria

Corresponding Author: Adaoma Igwedibia, E-mail: adaoma.igwedibia@unn.edu.ng

\section{ARTICLE INFO}

\section{Article history}

Received: August 20, 2017

Accepted: October 27, 2017

Published: January 05, 2018

Volume: 7 Issue: 1

Advance access: December 2017

Conflicts of interest: None

Funding: None

\begin{abstract}
A number of works have been done by scholars on the study and interpretation of Audre Lorde's poetry, especially through the lens of literary and critical analysis. However, Lorde's poems have not been analyzed pragmatically. A lot may have been written about Lorde's poetry, but there is absolutely no evidence of a pragmatics study of her work. Lorde is the author of many poems that have been studied in various theoretical dimensions, but none have been done with reference to their pragmatics implications. The problem which this research recognizes, therefore, is that Lorde's poems, especially the ones under the present study, have not been studied and interpreted using Grice's theory of Conversational Implicature (Cooperative Principle) which is comprised the four maxims: the maxims of Quantity, Quality, Manner and Relation. This study seeks to discover the extent to which these maxims could be applied to the reading of the selected poems of Lorde. It also seeks to ascertain the degree to which Lorde's selected poems violate or adhere to these maxims. The study has found that Audre Lorde in some of her poems, violates the maxims as well as adheres to them both in the same breath.
\end{abstract}

Key words: Conversational Implicature, Pragmatics, Grice, Poems, Maxims, Cooperative Principles, Audre Lorde, Context

\section{INTRODUCTION}

Experiences have shown that what people say or write is not always what they actually mean. Quite often, speakers' or authors' utterances or writings mean much more than what they actually literally say or write. For instance, a speaker who sends someone on an errand might say, "If you like, don't come back today." This statement might have the implied meaning of, "Return as soon as possible or come back very quickly." This is in line with the view of Jenny Thomas (1995, p. 1) who posits that "people do not always or even usually say what they mean." He illustrates this with these examples: "it's hot in here." This statement is open to varying interpretations. For someone who came into a room with the windows shut, this might mean 'please open the window.' Or it might mean, 'Is it alright if I open the window?' Or 'You're wasting electricity.' What someone says at times can be the complete opposite of what he or she means. Thomas suggests that people can mean something quite different from what their words suggest.

The preceding exposition lays out the problem of meaning in context, specifically how context contributes to meaning. Grice, writing on the same subject, studies a sort of talk-in-interaction, raising questions such as: do speakers mean what they say, or say what they mean? In other words, he studies context-dependent aspects of meaning. We will return to Grice momentarily. Meanwhile the present study seeks to investigate the features of the speech context embedded in the poetic lines in Audre Lorde's poems, arguing that context helps determine which proposition is expressed by a given poetic line. The meaning of those lines can be regarded as a function from a context, including time, place, and possible worlds shared by both poet and readers, into a proposition, where, as Robert C. Stalnaker (1972, p. 383) argues, a proposition is a function from a possible world into a truth value. In other words, the study investigates aspects of meaning involved in the interaction between a poetic expression's context of utterance and the interpretation of elements within that expression. An important aspect of Audre Lorde's language use in her poetry is one that takes context into account as an essential part in the construction of meaning.

Returning to Grice, one of his two most influential contributions to the study of language and communication is his theory of meaning, which he began to develop in his article "Meaning," written in 1948 but published only in 1957 at the prodding of his colleague, P. F. Strawson (Wikipedia) Grice further develop his theory of meaning in the $5^{\text {th }}$ and $6^{\text {th }}$ of his William James lectures on " Logic and Conversation," delivered at Harvard in 1967. These two lectures were initially published as "Utterer's Meaning and Intentions" in 1969 and "Utterer's Meaning, Sentence Meaning, and Word Meaning" in 1968, and were later collected with the other lectures as the first section of Studies in the Way of Words in 1989. But 
Grice's most groundbreaking contribution to philosophy and linguistics is his theory of implicature which started in his 1961 article, "The Causal Theory of Perception," and is most fully developed in his 1967 "Logic and Converation." According to Grice (1967), what a speaker means by an utterance can be divided into what the speaker "says" and what the speaker thereby "implicates." This results in what Grice calls Conversational Implicature. To conversationally implicate something, according to Grice, is to mean something that goes beyond what one says in such a way that it must be inferred from non-linguistic features of a conversational situation together with general principles of communication and cooperation. To Grice, a conversational implicature, is, therefore, something which is implied in converasation, that is, something which is left implicit in actual language use. In other words, implicature provides some explicit account of how it is possible to mean more than what is actually said. Grice then goes on to propound his theory of implicature which he calls the Cooperative Principle. The Cooperative Principle, according to Grice is a norm governing all cooperative interactions among humans and it consists of four conversational maxims.

From the foregoing, one could simply ask the question as to why the speakers' utterance can mean different things at different times on different occasions. Another question is how do we interpret what the words actually mean on a certain specific occasion? And why don't people just say what they mean? According to Thomas (1995, p. 1-3), several interesting questions arise from observations. He asserts: "If speakers regularly mean something other than what they say, how is it that people manage to understand one another if a single group of words such as "it's hot in here" could mean so many different things at different times, [in different contexts], how do we work out what it actually does mean on one occasion as opposed to the other? And why don't people just say what they mean? To him, these and many other similar issues are addressed within the area of linguistics known as pragmatics. Simply put, pragmatics is a field of study that shows how language is used to send messages that are not directly related to the additive value of the raw linguistic data of the utterance. Thomas (1995, p. 1-2) posits that "in the early 1980s, when it became common to discuss pragmatics in general textbooks on linguistics, the most common definition of pragmatics was: meaning in use or meaning in context, in other words, contextualized meaning.

Patrick Griffiths (2006, p. 1) sees semantics as

the study of the "toolkit" for meaning: knowledge encoded in the vocabulary of language and in its patterns for building more elaborate meanings, up to the level of sentence meanings. Pragmatics [on the other hand] is concerned with the use of these tools in meaningful communication. Pragmatics is about the interaction of semantic knowledge with our knowledge of the world, taking into account contexts of use.

The above definition shows that semantics is concerned with meaning at the level of the formal meaning, which is more or less the literal meaning of a sentence. Pragmatics, on the other hand, goes beyond the literal meaning of a sentence, concentrating, instead, on the contextual level of meaning. In speech and writing, the choice of words and sentences depends fully on the speaker or the writer, leaving the reader or the hearer with information he/she has passed on or written.

Audre Lorde's poetic language generates internal meaning. In particular, this study seeks to examine and analyze the deeper, inferred " social force" of language in Lorde's poems. The clearest way Lorde communicates her ideas and thoughts is through language. To achieve this, the ideas and thoughts she wishes to communicate become encoded either phonologically (by the sound of the spoken words) or graphically (through marks on a printed page). When this meaning is conveyed semantically, the encoded meaning - the words, phrases and sentences Lorde creates - can be easily decoded without particular thought of the context. Sometimes, however, a deeper, inferred meaning is also encoded within her language, and this creates a pragmatic force within the text. Thus, this study rests on the proposition that whenever Lorde writes or says something semantically in her writing, she means to infer extra force to her utterance.

Surface readers of Lorde's poems ignore the pragmatic force of her language in their analysis and thus lose many critical marks and deeper levels of meaning in her writing. This study hopes to correct this imbalance or this neglect. An example will make this clear. In her poem "The Black Unicorn," we read the following lines:

The black unicorn is greedy.

The black unicorn is impatient.

The black unicorn was mistaken

for a shadow.

The meaning these lines embody will very much depend upon the social and historical circumstances in which they are couched. It is the adjectives - 'greedy, 'impatient,' and 'mistaken' that, in certain social/historical situations, will carry different levels of force. In other words, they are pragmatically loaded words whose meaning can only be inferred by the context of the language use. For instance, the poet in the preceeding lines just quoted employs the striking images of a greedy and impatient protester to infer the urgency of the situation, that of social justice. Pragmatics meanings can be inferred in this way because, owing to the context of the language use, careful analytical readers are able to read into a word the extra meaning-the utterances' pragmatic forceconferred upon it by the way it is used within a particular social situation.

The application of pragmatics to Audre Lorde's poems allows us to see how language is used in interesting and social ways: knowing that a listener or reader of Lorde's poems shares certain knowledge with the poet by allowing his or her conversation with the poet/speaker to be more personal, lively or less extended. It also allows us to use words and give them inferred elements such as power aspects, because Lorde's listener/reader is aware of her social standing. Similarly, Lorde's poetic language can act in ideological ways to reinforce African American societal values, again pragmatically. The following lines from Lorde's poem, "From the House of Yemanja": 
where she cooked up her daughters

into girls.

before she fixed our dinner.

My mother had two faces and a frying pot

require more than a semantic analysis to reveal the intended meaning of the words and phrases. This study rests on the assumption that Lorde's poems are about the intersection of language and power, just as they underscore or exemplify the important areas of pragmatics. The implicit understanding of a power relationship between, for instance, two speakers in an interlocution, is often indicated by the meaning implied by the language used. And this meaning can be very context-dependent.

The study rests on the conviction that a recognition of speaker intention conditions success in overall interpretation of Lorde's poetic utterance. Reboul and Moeschler (1998, p. 93) posit that interlocutors [in this case, in Lorde's poems] arrive at a satisfactory interpretation of the utterance, if they succeed in recovering the contents that the speaker intended to communicate by means of that utterance. For Grice (1975),meaning and intention are never explicit and transparent; they can only be recovered, thanks to the implicit elements. As has been stated earlier, Lorde's poems have not been subjected to detailed pragmatics analysis of the kind intended by this study.

\section{Statement of the Problem}

Audre Lorde's writing apparently constitutes a major propelling force in the growth of postcolonial and cultural studies. Several works have been done by scholars on the study and interpretation of Lorde's poems, especially through literary/ critical analysis. It is quite obvious that Lorde's poems have not been subjected to a pragmatics analysis. A lot may have been done or said about Lorde's poems, but to the knowledge of this researcher, there is absolutely no evidence of the aspect of pragmatics in this regard. Poems are supposed to be studied and interpreted using suitable apparatuses. Lorde's poems have rich pragmatics implications and potentialities that can be better understood when subjected to a deep contextual analysis. The problem which this research recognizes, therefore, is that Lorde's poems have not been studied and interpreted using pragmatics principles. The need to solve this problem has led the researcher to embark on the study of the poems based on the theory of Conversational Implicature.

\section{Objectives of the Study}

The general objective of this study is to undertake a pragmatics interpretation of Lorde's poems based on the principles of conversational implicature. In specific terms, the study is designed to:

1. Examine the degree to which Audre Lorde's selected poems violate or adhere to the Maxims of Quantity, Quality, Manner and Relation.

2. Provide possible interpretation of selected poems based on the violation of Grice's Cooperative Principles.

\section{LITERATURE REVIEW}

\section{Review of Relevant Literature in the Field}

A pragmatics account of literature makes it clear that in literary communication we not only have a literary text, but also the emotive effects of literary interpretation which include the needs, wishes, desires, likings and feelings of the author. Pragmatics, as we know it, is that level of linguistic analysis which studies meaning in context. Yule (as cited by Osisanwo, 2003, p. 55), asserts that pragmatics is "concerned with the study of meaning as communicated by a speaker (or writer) and interpreted by the listener (or reader)." When one talks about pragmatics, one is simply talking about meaning beyond the linguistic data, that is to say, that pragmatics takes care of the implied meaning of an utterance which could only be inferred within the context. The pragmatics of literary communication deals with the kinds of problems, such as the kinds of actions accomplished by the production of the literary text (i.e. the poem), the appropriate conditions of those actions, and the relationships between the actions and their contexts (Van Dijk, 1981, p. 13-16). A text induces its interpreter to construct an image, or maybe a set of alternative images. While the image construction and image revision are going on, the interpreter also tries to figure out what the creator of the text is doing - what the nature of the communication situation is all about. For any successful interpretation, then, the reader has to draw up a set of inferences from where the contextual implication can be derived. Understanding and interpreting poetry requires understanding and appreciating of historical and social conditions and ideological factors under which the writers find themselves. Therefore, the pragmatics impact of the poem embraces the totality of the poem, combined with its emotional, intellectual and imaginative appeal (Indede, 2009, p. 107).

Different scholars and critics of literary works have introduced important notions which either oppose or consent with the theory of pragmatics. Among these critics is Emmanuel Ngara who considers literary works as communicative utterances produced by the author and received by the reader (or hearer), especially when the poem is read aloud. He clearly maintains that a poem is not like everyday speech in that it is patterned in order to give its communicative effects a greater impact. He goes further to say that the impact of a poem could be derived from the totality of the poem, from the weight of its message combined with its emotional, intellectual and imaginative appeal (p. 14-15).

These views intelligibly coincide with Van Djik's (1981, 246-247) who observes that not only are the structures of literary texts important, but also their functions as well as their conditions, their production, processing and reception. The fact remains that poor attention to cognitive analysis of literary communication can bring about poor insight into the emotive effects of literary interpretation which involve our needs, wishes, desires, likings and feelings.

H. P Grice was the first scholar to make a distinction between what the speaker says and what he implies. The idea of "say" is closely tied to the words actually uttered and their ordinary meanings, but more so it includes all the references 
and predictions that result from that utterance, and whatever force, direct or indirect, it might have (Martinich, 2008, p. 508). It is important to note that most of the poems displayed by the composers are metaphorically expressed. Metaphorical meaning is therefore not explicit in utterance. In line with this, John Searle (1969, p. 502) differentiates speaker's meaning when he utters words from sentence and expression meanings. For the poet to communicate using metaphorical, ironical, and allegorical sentiments, there must be principles according to which he is able to have more than one meaning, or something different from what he says, whereby the reader using them can understand what he or she means.

This paper is designed to comprehend the pragmatics of the poetry of Audre Lorde. The study, therefore, employs the Cooperative Principle developed by Grice whose Conversational Implicature is central to the discussion. Even though Grice's fundamental explanations deal with natural conversations, one should not neglect the fact that the general display of his approach to discourse gives room for the analysis of literary texts. The conversational strategies in literature and more so in poetry as will be discussed in this study invite an open-ended world in which the reader acts creatively, just like the author, if both of them have to share the meaning and meet communication goals (Indede, 2009, p. 108). The literature review in this study is designed to accommodate the pragmatics analysis of poetry of and critical works on Audre Lorde.

In her essay entitled "A Pragma-Stylistic Analysis of Robert Frost's Poem 'the Road Not Taken," Dyah Rochmawati attempts an analysis of Robert Frost's poem, the Road Not Taken from the perspective of pragmatics and stylistics. He asserts that a pragmatics account of literature assumes that in literary communication we do not only have a text, but also the emotive effects of literary interpretation involving needs, wishes, desires, likings and feelings of the author by using Grice's Cooperation Principle. Rochmawati's analsysis does not include any pragmatics analysis of Audre Lorde's poetry, and so creates a gap that needs to be filled.

Florence Indede (2009) in her article entitled "The Pragmatics of Kiswahili Literary Political Discourse" attempt a pragmatics analysis of Kiswahili literary political discourse using Grice's Cooperative Principle. She bases her analysis on the following poetic texts: Chembe cha Moyo by Alamin Mazrui, Sautiya Dhiki by Abdilatif Abdala and Jiho la Ndani by Said Ahmed Mohamed. She maintains that her article employs the Cooperative Principle developed by Grice whose Conversational Implicature is central to her discussion. She argues that the interpretation of meaning requires high level of application of the Cooperative Principle by both the reader and the author. Indede avers that the poetic dialogic understanding of the author's theme or message involves recognizing his rationale for using an utterance in context. Indede's analysis, as in Rochmawati's, provides a robust pragmatics analysis of selected Kiswahili political discourse poetry, but once again no reference to diaspora poetry in general nor to Audre Lorde's poetry in particular. Hence, there is an existing lacuna that my study will address.

The reviews that follow are purely literary and critical analyses with no evidence of pragmatic reading of Lorde's poetry.
In her brilliant essay, "Living on the Line: Audre Lorde and Our Dead Behind Us," Gloria T. Hull avers that Lorde's seemingly essentialist definitions of herself as black/lesbian/mother/woman are not simple, fixed terms. Rather, she argues that they represent her ceaseless negotiations of a position from which she can speak. Hull proffers examples of these ceaseless negotiations to the effect that almost as soon as she achieves a place of connection, she becomes uneasy at the comfortableness (which is, to her, a signal that something critical is being glossed over) and proceeds to rub athwart the smooth grain to find the roughness and the slant she needs to maintain her difference-defined, complexly constructed self. Secondly, Hull focuses specifically on Lorde's poetry volume Our Dead Behind Us which she suggests is in constant motion, with poem after poem enacting a series of displacements. Third, Hull zeroes in on the cover of Our Dead Behind Us which consists of "a snapshot of the last Dahomean Amazons," and "three old Black women in draped clothes," superimposed upon a sea of dark and passionate South Africans at a protest demonstration. This image, Hull contends, projects Lorde's membership in a community of struggle which stretches from ancient to modern times, speaking into exclusionary space a transcendent black woman power "released/from the prism of dreaming."

Rachel A Dudley (2006, p.16-39) follows suit in her equally illuminating article ("Confronting the Concept of Intersectionality: The Legacy of Audre Lorde and Contemporary Feminist Organizations,") by asserting that Audre Lorde is one of many women to criticize second wave feminism for overlooking issues of intersectionality. In specific terms, she critically examines the ways in which Lorde introduced intersectionality into feminist discourse and how feminist organizations embrace this concept today. The question Dudley poses is this: have feminist organizations confronted the concept of intersectionality within their work; in other words, do they account for the multidimensionality of women's lives while fighting for economic, political and social equality; and do they see inter-sectionality as a central tenet of feminist organizing. All these questions, argues Dudley, bring us closer to an understanding of how concepts deemed important by a small group can become permanently relevant within feminism and by extension within society.

Robina Josephine Khalid (2008, p.3-4) in her essay ("Demilitarizing Disease: Ambivalent Warfare and Audre Lorde's 'The Cancer Journals,") presents literary criticism for the 1980 nonfiction work The Cancer Journals by Audre Lorde and offers a discussion of the power and difficulty surrounding the issue of breast cancer for women in general and Audre Lorde in particular. She describes in detail how the disease ravages the body and Lorde's physical and psychological struggle against it. Khalid focuses on Lorde's nonfiction work, The Cancer Journals. There is absolutely no reference to pragmatics.

Consuelo Rivera-Fuentes, a Chilean poet, activist, and lecturer (in "Sister Outsider: An Enduring Vision: Embracing Myself, My Sister and the 'Other,'") reflects on and reacts to Audre Lorde's critique of racism within lesbian communities. Her purpose is to honour and rescue Lorde's 
wonderful insight into the power of words when uttered and shared by women, as well as her ideas about differences and connections that exist between black and white feminisms. Grounded in her own experience of alienation and racism in the European context of Women's Studies, Rivera-Fuentes then asserts that Lorde's insistence on a 'sisterhood' embraces the 'other' and ourselves at the same time.

Pracheta Bakshi (2014, p.8-13) (in “Audre Lorde's Exploration of Her Multiple Selves in Her Biomythography Zami: A New Spelling of My Name") argues that Eurocentrism, or to be specific, Eurocentric feminism has always disregarded the female experience of the "Other"- be it the socio-political context or the philosophical undercurrent or the mythological projections of African. Therefore, Bakshi asserts that Audre Lorde in her life writing has radically endeavoured to explore her multiple selves, her radical female subjectivity, insisting that the African Orisha, i.e. the androgynus, ambiguous, trickster, mythological figure is re-invoked in her writings, especially in her poems and her "Biomythography." Bakshi then concludes by saying that Lorde has successfully established her Afro-centric female identity by discarding the Graeco-Roman mythological tradition as a totalizing telos.

Eric Sipyinyu Njeng ((2007, p.23-36) (in "Lesbian Poetics and Poetry of AudreLorde") makes an ontological diagnosis of lesbian experience. Using Audre Lorde as a prime example, Njeng argues that for Lorde, lesbianism is natural, liberating, political and ultimately creative. Lesbianism is natural because, for Audre Lorde, it springs from the primal desire for the mother. Viewing heterosexuality as oppressive, lesbianism frees the woman from the inexorable strictures of patriarchy. Politically speaking, Njeng contends that even heterosexual women can and do resort to lesbian acts when they are asphyxiated with patriarchy.

The literature review gives vital insight into the pragmatics analysis of poetry and others that focus specifically on the critical interpretation of Audre Lorde's writings, especially her poetry. The literature review shows that no research has been carried out to pragmatically interpret and analyze Audre Lorde's poetry. This observation has provided a fresh impetus for the researcher to continue the study so as to fill the existing lacuna.

\section{METHODOLOGY}

In this work, pragmatics principles, specifically, Grice's Cooperative Principle which include the four Maxims, have been applied to the study of Audre Lorde's two selected poems. The method involves the analysis of Lorde's two poems using Grice's theory of Conversational Implicature to see how its maxims could be applied to a reading of meaning in the two poems.

\section{Design of the Study}

The study is a pragmatics analysis of Audre Lorde's poems. The design the researcher employs is analytic survey. Analytic survey or what is known as cross- sectional study involves the testing out of two hypotheses. The first is ascertaining if Lorde in the two poems violates the four maxims of Grice; and the second involves whether she adheres in the two poems to the four maxims of Grice. The target population or the sampling group comprises the poems, "The Black Unicorn" and "From the House of Yemanjá." It is involved with the collection and analysis of these poems with special reference to their pragmatic implications in relationship to the explanatory variables.

\section{Population for the Study}

According to Nworgu (2006, p. 94), a population refers to the "limits within which the research findings are applicable." In other words, a population has to do with the elements to which the results or the outcomes of investigation are generalizable. The population for this study is, therefore, the two poems of Audre Lorde under this study.

\section{Sampling}

Sampling is the selection of some members or elements from the population for actual investigation. This selection is necessitated by the impracticability of studying the entire population in most cases (Ohaja, 2003, p. 20). In this work, the following poems are selected since all the poems of Lorde could not be handled in a study of this nature:

- The Black Unicorn

- From the House of Yemanjá

The selection is based on the fact that these poems invariably cut across the major sensitive areas of societal life such as race, politics, education, economy and religion. Purposive sampling technique is used to do the selection. Purposive sampling technique simply means the selection of specific elements for research investigations. According to Nworgu (2006), "in purposive sampling, specific elements, which satisfy some predetermined criteria, are selected."

\section{Instruments for Data Collection}

The researcher makes use of documented poems of Audre Lorde, especially those that concern race, politics, religion, education and economy. Also used are some published and unpublished materials on the activities of public and private organizations. Library material are extensively explored for detailed information on conversational implicature and its application to text analysis. The researcher also makes use of internet for currency, modernization and global standard.

\section{ANALYSIS}

\section{"From the House of Yemanjá"}

In the poem, "From the House of Yemanjó," Lorde tells the story of a mother who has two faces, and two daughters, one white, one black, and obviously the poet-speaker is the black one, but the mother suppresses and silences her blackness. The mother is notorious for suppressing blackness and upholding whiteness in such a way that whiteness is 
supposedly superior to blackness. The whiteness is upheld as the norm and the mother wants her daughter to embrace that norm and forget about her blackness because blackness equals difference. The poet-speaker makes it perfectly clear that this is the United States where, of course, whiteness is normalized as identity and held up high for everybody to emulate. So whiteness is what is held up in society for everybody to emulate and blackness is what nobody wants to associate with because blackness is seen as synonymous with inferiority, even diabolism. This is what Audre Lorde emphasizes in the sense that once you are black, everybody sees you as a "ghetto" person. The poet-speaker's mother worships whiteness, but Lorde wants her to accept her blackness and not cook her into what she does not want to be by trying to suppress her identity as a black person. The daughter makes it clear to her mother that a "super star" can come from a "ghetto," that she should learn to appreciate what she has. There is a fundamental dialectic/tension between whiteness that is affirmed and promoted and privileged for the daughter to emulate, on the one hand, and the blackness that the daughter has chosen deliberately for herself instead, on the other. This is the main intellectual thrust of this poem-two warring ideals, according to W.E.B. DuBois-whiteness and blackness, with the mother privileging whiteness better than blackness and the daughter on the other hand, privileging blackness.

To fortify her argument in privileging her blackness, she falls back on the African mythological tradition of the Orisha. Why does the poet-speaker fall back on the Orisha mythology? The reason is that Yemanjó is one of the female deities of the Orisha. Orisha is the Yoruba deity pantheon that encompasses a lot of gods and goddesses of which Yemanjó is one of the prime goddesses. One of the characteristics of Yemanjó which Audre Lorde admires is that she is self-assertive, bold and commands respect and adoration even among the male deities. She is fearless and audacious. The speaker flies to Yemanjó's patronage in order to emulate black role models, black superstars. The speaker reminds us of Jamaica Kincaid's girl in "Girl" in her title novel From the Bottom of the River. The girl's predicament is similar to the speaker's in "From the House of Yemanjó." In both the poem and the story, the protagonists are in opposition with their respective mothers. In both poem and story, both poet and novelist interrogate the role of the mother in shaping the daughter's place in the culture and society. In the fourth stanza, the speaker calls a spade a spade,

Mother I need

Mother I need

Mother I need your blackness now

As the august earth needs rain.

She is hungry for her blackness which her mother is suppressing. She doesn't want to grow into whiteness. In the final stanza, the speaker talks about harmony of creation, insisting that the natural indicators, sun and moon, must co-exist. It is not a question of either this or that. The cosmic law of God is that two dissimilar things must co-exist to achieve harmony. God has created white people and black people to co-exist and live in harmony. The last stanza is a metaphysical reassertion of the divine law of God that things that are created by God must co-exist.

In the poem "From the House of Yemanjó," we perceive the use of two metaphors - "my mother had two faces and a frying pot." These metaphors convey the image of a mother wielding a frying pot. The frying pot here is not your ordinary frying pot but instead represents an instrument by which the mother molds her daughters into the image of white society. There is an implied comparison between her daughters and their construction into the image of white society. "A frying pot" is a metaphor of social construction which the speaker's mother is using to construct her daughters into the image of white society. In a way, the frying pot is symbolic in that it represents the attempt by the mother to forge these young girls, her daughters, into something that they are not. The statement "My mother had two faces" is also a metaphor which speaks to the divided loyalties of the speaker's mother-one geared towards whiteness which she acknowledges and privileges, the other prone to blackness which she debases. The question then for the poet-speaker is what choice does she make in the circumstances-does she embrace whiteness and reject her blackness or does she embrace her blackness and accept who she is? She accepts the latter, and that acceptance is the source of tension between her and her mother.

In the second stanza, the poet-speaker expands on the metaphor of two faces - one dark and rich and authentic, the other white, false and adulterated - "pale as a witch." The poet-speaker makes her choice for the former which is dark, rich and authentic - her black identity. Having made her choice, the poet-speaker makes a declarative statement about that choice:

Mother I need

Mother I need

Mother I need your blackness now

As august earth needs rain,

Insisting on her black identity and rejecting the white image being thrust upon her or being rammed down her throat by what Ikenna Dieke (Lectures, University of Nigeria, Nsukka, 2012) has called 'traditional whitocratic socialization.'

\section{Grice's maxim of quantity to audre lorde's" from the house of yemanjá"}

By involving the natural indicators, "the sun and moon" and associating them with one of the daughters, the speaker seems to be reaching for a hyperbole. Hyperboles are exaggerated language employed to heighten awareness or consciousness. Grice claims that hyperboles can be analyzed in terms of conversational implicatures. The element of exaggeration underscores a profuseness which points to a propensity to say too much beyond what is traditionally sufficient to make a point. For instance, in stanza one, the speaker could perfectly have stopped with the line "who was not me" but because she is trying to underscore the difference between her and her white sister, she expands her consciousness to include the cosmic order. The reference to the cosmic order is not necessary, but it is only an attempt to deepen the gulf 
between the speaker and her other sister. In that respect, the speaker tends to say too much, more than enough to explain the difference between her the black sister and her white sister. Since the ground rule of Maxim of Quantity delimits the quantity of information to be provided, it becomes perfectly clear that the speaker ignores this limitation; in other words, the speaker violates this important maxim of the Cooperative Principle.

\section{Maxim of quality}

The Maxim of Quality has two provisos: Do not say what you believe to be false; do not say that for which you lack adequate evidence. In the first stanza of "From the House of Yemanjó," there is clear evidence that the first proviso of the Maxim of Quality has been violated in the sense that the speaker creates the impression that she desires the eyes of her twin sister who is white: "I am the sun and moon and forever hungry/for her eyes," but in actuality, she resents that. The lines in stanza four belie this impression created. The following lines in stanza four stand in opposition to the impression that she desires her eyes, her twin sister's eyes;

\section{Mother I need}

mother I need

mother I need your blackness now

as the august earth needs rain.

Additionally, in the last stanza, stanza five, there is a dialectic between whiteness and blackness in the sense that both entities maintain their distinct identities, and so can never merge and become one. The speaker says:

I am

the sun and moon and forever hungry

the sharpened edge

where day and night shall meet

and not be

one.

This final pronouncement lays to rest the notion that black people can merge into white people and come out looking the same. Instead, the speaker cherishes and celebrates difference and abhors her mother's tendency toward sameness. The hyperboles in the preceding stanza violate the maxim of Quality which says: Do not say what you believe to be false. The hyperbolic declaration in the same stanza could be linked to the fact that the alleged implicatures in this poem are patent violations of the maxim of truthfulness.

The story line in "From the House of Yemanjó," is that of a mother who is alienated from one of her daughters because of her perceived attempt to turn her into what she is not. In doing that, she introduces an ostensibly irrelevant metaphor - two natural indicators, the sun and the moon, and the question the reader consistently asks is: what is the relevance of these two cosmic entities and the estranged daughter. The reference to these cosmic indicators is repeated in the last stanza, and there seems no sane justification for that. In effect, the reference to the cosmic metaphor of the sun and moon suggests an irrelevancy that bears no logical relationship with the situation that the daughter is in. But even if we were to grant that there is a relevance, the metaphor seems far-fetched in its present configuration. Granted that what the daughter is referring to is her naturalness as a black woman, she could have quite easily said that without invoking the cosmic order, but by invoking the cosmic order to describe a simple process of black beauty introduces an ambiguity and a needless obscurity of expression. Therefore, that expression with the sun and moon violates the maxim of manner.

\section{"The Black Unicorn"}

There are two senses in which to understand the meaning of a unicorn. A unicorn is an animal that does not really exist. In another sense, a unicorn is a mythical creature resembling a horse. Let us look at the meanings in terms of racial politics in the United States. The first meaning has implication for racial politics in the sense that historically the black person is equated to an animal and if the black person is equated to an animal, then it means that he does not share in the privileges of humanity. This was what informed the ideology of the Trans Atlantic Slave Trade. When you subject human beings to an animalistic treatment then you create the impression that fundamentally they are not humans but animals. The assumption in the West is that black Africans are not really human and so must be subjected to inhuman treatment. But if the black person were a human being, therefore, it would follow that they must treat him as such and so have no right to oppress him, to denigrate him. In the second meaning, the black person is seen as a horse and as a horse must be subjected to inhuman labour. Being a mythical figure suggests that a black person exists in the white man's imagination as a myth.

By entitling her poem "The Black Unicorn" Audre Lorde seems to be parodying the Western notion of the black person as something resembling an animal. Back to the first meaning, the fact that a unicorn does not really exist speaks to the fundamental or perceived invisibility of the black person in Western epistemology (the whole domain of knowledge). Hence, Ralph Waldo Ellison, the African American novelist, speaks of that perceived invisibility and the consequences of it in his signature novel Invisible Man. In the first three lines in the first stanza, Audre Lorde parodies the comparison between black and unicorn. She suggests that unlike unicorns that do not really exist for real, Black people do exist for real. Black people are a reality. They are real in flesh and blood. They are not shadows but human beings created by God. They have emotions to become offended and the intellect to understand that they have been offended. The black unicorn is impatient because he cannot wait to gain his freedom. This is because the black unicorn is mistaken to be a shadow that does not have emotions or a symbol in the sense that black people are symbols of primitive tribe or primitivism from a primitive Africa, what Joseph Conrad calls in his novel "heart of darkness." The blacks have their needs. They are not unicorns. They are impatient and protesting their captivity and demanding their freedom and equality. In a clear reference to American slavery, Audre Lorde says that the Black Unicorn was "taken through a cold country where mist painted mockeries of my fury." Here, she talks about how black people were forcibly taken from tropical Africa to temperate climate, the 
United States in particular through the so called Middle Passage. One of the characteristic elements of Lorde's writing is the presence of intense palpable anger, and in this poem, the inhuman treatment of black people in the United States provokes that intense anger in her. The anger vibrates within the vocabulary she is using. The anger is steaming within her almost uncontrollably. Her anger is first the enslavement of black people, then their discrimination in various institutions in the United States, then the Jim Crow laws of the South, etc. The black unicorn wants his freedom now and he is restless and unrelenting.

The last line in stanza two - "the black unicorn is not free" undermines what Ikenna Dieke (2010) describes in his book Allegory and Meaning as the familiar American functional idealism enshrined in the preamble to the American Constitution which is: "All men are created equal/that they are endowed by their Creator with certain unalienable rights, that among these are Life, Liberty, and the Pursuit of Happiness." It undermines it because Audre Lorde is saying that despite what is enshrined in the preamble to the American Constitution, the reality on the ground is that black people in the United States are not really free and that is why the speaker and by extension black Americans are unrelenting in their personal and collective resolve and struggle to be free and achieve true equality with white people in a society built on solid equalitarian principles. The reason that the black is restless or restive is that he is still in captivity two hundred years after the Revolutionary War (the War of Independence). The speaker challenges the Western assumption that blacks are strange creatures or anything other than human beings while the unicorn is perceived as a beast. But the speaker is adamant that black people are not beasts. Instead, they are human beings with feelings and desires, and when their feelings are punctured, they will be angry and their anger is justifiable. The only parallel between the beast and the black is the one forced on the latter by whites who through slavery have turned black people into beasts of burden. The speaker insists that the black people should be respected and granted their rights and here and now. And because these rights have been taken away from them, the speaker is infuriated. Unicorns are supposed to be silent, being able to move without making any sound. The speaker insists that black people will never be silenced as long as they have a soul in them. They must speak up against their curtailed freedom, against their captivity, against those that are responsible for and implicated in that captivity.

"The Black Unicorn" is a protest poem. A protest poem is a poem in which the speaker registers disapproval of the status quo. And that status quo is the oppression of black people. In short, Audre Lorde in this poem is serving a notice that African people will no longer keep silent in the face of their oppression and denial of their basic/fundamental right. The speaker is saying something like this: "If you thought we would be silent, you had something coming for you." "If you thought we would forget our history, about what happened to our people, you had better think again." "Our history is a history of brutality, of man's inhumanity to man and we as great great grandchildren of the slaves know what happened to our people in the course of history, in the course of the trans-Atlantic slave trade." The speaker seems to be saying also, "you can call us whatever name you choose to call us, the truth is that we are inheritors of a great people-African people and we are here to call attention to that-We also are here to reclaim what is rightfully ours."

\section{Grice's maxims to audre lorde's "the black unicorn"}

Speaking pragmatically, in "The Black Unicorn," Audre Lorde violates the Maxim of Quality in the first seven lines of the poem's first long stanza;

The black unicorn is greedy

The black unicorn is impatient

The black unicorn was mistaken

for a shadow

or symbol

and taken

through a cold country.

Based on what is evident in the preceding literary analysis, the black unicorn could not be greedy, impatient and mistaken since the speaker has already told us that black people are not only desirous of their freedom but that they have a right to desire that freedom, to hunger and thirst for that freedom. So it seems quite unlikely that the speaker meant to say that the black is greedy, impatient and mistaken. Knowing full well the chequered history of black people in the United States, the speaker's intended meaning is that black people are justified in their demand for social justice.

The last stanza of the poem,

The black unicorn is restless

the black unicorn is unrelenting

the black unicorn is not

free.

Conveys the real communicative intention of the speaker which she employs in the first stanza that depicts verbal irony. Her use of verbal irony in stanza one, therefore, violates the maxim of Quality, for according to Grice, verbal irony is a blatant violation of the maxim of Quality. The reason is that the speaker intends to convey only what is conversationally implicated: the conversational implicatures of the utterance, thus have to be seen as cancelling what is actually said. Her use of verbal irony indicates the fact that an implicature has to be substituted for what was literally said ought to confirm the hearer's suspicion that the maxim has been violated rather than preserving her assumption that it has been obeyed. In other words, the implicatures carried by irony do not seem to be at all of the same as more standard implicatures; they do not satisfy the same definition, and they must be worked out according to rather different principles. Verbal ironies in stanza one have as counterparts in the last stanza of the poem from which they violate the maxim of Quality. But in the last four lines of the second stanza, the speaker adheres to the Maxim of Quality

The black unicorn is restless

the black unicorn is unrelenting 
the black unicorn is not

free.

This adherence is borne out of the natural tendencies of human beings to be free. And African Americans being bona fide human beings are freely expressing their innermost desires to be free from any encumbrances, prohibitions and interdictions. Any soul being encumbered must hit and spit at those forces holding her back and down. The speaker obeys the Maxim of Quantity by providing adequate information about what happened to black people in the history of slavery and the history of black culture displacement, occasioned by slavery. By conflating black history and the politics of racial oppression, the speaker makes the strongest statement ever on the need for blacks to actualize their deferred dreams. The poem is characteristically brief and pointed in its rhetoric. In its sixteen lines, the poem tells the story in simple language about the agony of the Middle Passage (the Transatlantic Slave trade) and the struggle of black people in America to be free and equal under the sun, in a society founded on the principles of democratic egalitarianism. The language is simple and straight-forward; there are no elaborate metaphors, no obscurity, and no ambiguity. The poet is visibly angry and she minces no words about it. But the verbal ironies used in the first stanza:

The black unicorn is greedy.

The black unicorn is impatient.

The black unicorn was mistaken

for a shadow

Tend to violate the Maxim of Manner. In the last stanza, the poet calls it the way it is. And so it adheres not only to the Maxim of Relation but also to the Maxim of Manner.

\section{CONCLUSION}

This study has been an attempt to read Audre Lorde's selected poems as conversations between speaker and listener in terms of the speaker's intent beyond the literal level of meaning, in other words, the implied or pragmatics meaning of what the speaker says and the extent to which the listener understands the context of meaning. What the researcher is saying is that to understand Audre Lorde in her poetry, especially in the poems selected, one must go beyond the semantic or literal meaning of words, concentrating instead on the contextual level of meaning, in other words, the inference that listener and the reader constructs. In Lorde's poetry, especially the ones under the present study, the researcher has identified the three stages of pragmatics interpretation. The first is the semantic or literal stage where the selected poems are literally analyzed. The second is the stage of explicature where the interpretation of the poems is done through the use of contextual information to disambiguate certain expressions. The third stage involves implicature, that is, the pragmatics of hint.

The researcher has incorporated conversational implicature of Grice by adopting the Cooperative Principle, specifically the four Maxims which underpin the general rules we follow in conversation.

\section{REFERENCES}

Austin, J. L. (1962). How to Do Things with Words. Oxford: Clarendon Press.

Bakshi, P. (2014). “AudreLorde's Exploration of Her Multiple Selves in Her Biomytho-graphy Zami: A New Spelling of My Name." Abhinav National Monthly Refereed Journal of Research in Arts and Education.

Conrad, J. (2011). Heart of Darkness. Basingstoke: Palgrave Macmillan.

Dieke, I. (2010). Allegory and Meaning: Reading African, African American, and Caribbean Literature. Lanham, MD: UP of America.

Dudley, R. A. (2006). "Confronting the Concept of Intersectionality: The Legacy of Audre Lorde and Contemporary Feminist Organization."McNair Scholars Journal Studies.

Dyah, R. (2013). “A Pragma-Stylistic Analysis of Robert Frost's Poem " The Road Not Taken.” Jurnal Humaniora, Sains, vol. 1, 41-50.

Ellison, R. W. (1952). Invisible Man. New York: Random House.

Grice, H. P. (1975). "Logic and Conversation." Syntax and Semantics: Speech Acts 3. Eds. P. Cole and J. Morgan. New York: Academic Press.

Grice, H.P. (1991). Studies in the Way of Words. Cambridge, MA: Harvard University Press.

Griffiths, P. (2006). An Introduction to English Semantics and Pragmatics. Edinburgh: Edinburgh University Press.

Hull, G. T. (1989). "Living on the Line: Audre Lorde and Our Dead Behind Us." In Changing Our Own Words: Essays on Criticisms, Theory, and Writing by Black Women, edited by Cheryl A. Wall, 150-172. New Brunswick, N.J.: Rutgers University Press.

Indede, F.N. (2009). "The Pragmatics of Kiswahili Literary Political Discourse." The Journal of Pan African Studies.

Khalid, R. J. (2008). "Demilitarizing Disease: Ambivalent Warfare and Audre Lorde's The Cancer Journals." African American Review.

Lorde, A. (1978). The Black Unicorn. New York: Norton.

Lorde, A. (2000).The Collected Poems of Audre Lorde. New York: Norton.

Lorde A. (1985). "Poetry is not a Luxury." Sister Outsider: Essays and Speeches. New York: Crossing Press.

Martinich, A.P. (2008). The Philosophy of Language. New York: Routledge.

Ngara, E. (1990). Ideology and Form in African Poetry. London: James Currey.

Njeng, E.S. (2007). "Lesbian Poetics and the Poetry of AudreLorde." English Academy Review.

Osisanwo, W. (2003). Introduction to Discourse Analysis and Pragmatics. Lagos: Femolous Fetop Publishers.

Rivera-Fuentes, C. "Sister Outsider, An Enduring Vision: Embracing Myself, My Sister and the 'Other.'The Lesbian Studies Journal.1-9.

Reboul, A. \& Moeschler, J. (1998). Pragmatics of Speech. Paris: Armand Colin. 
Searle, J. R. (1975). "Indirect Speech Acts.” Syntax and Semantics: Speech Acts 3. Eds. P. Cole and J. Morgan. New York: Academic Press.

Searle, J. R. (1969). Speech Acts: An Essay in the Philosophy of Language. Cambridge: Cambridge University Press.

Searle, J. R. (1985). Expression and Meaning: Studies in the Theory of Speech Acts. Cambridge: Cambridge University Press.
Stalnaker, R. (1972). "Pragmatics.” In D. Davidson \& G. Harman, eds; Semantics of Natural Language, 380-97. Dordrecht: Reidel.

Thomas, J. (1995). Meaning in Interaction: An Introduction to Pragmatics. Essex, England: Longman.

Van Dijk, T.A. (1981).Studies in the Pragmatics of Discourse. New York: Mouton Publishers.

Yule, G. (1996). Pragmatics. Oxford: Oxford University Press. Online (http/www. Wikipedia.com). 